\title{
The Effect of Leadership Style and Work Environment on Employee Performance of Bnctl Branch Banks (Banco Nacional De Comercio De Timor-Leste)
}

\author{
Victoria Araujo de Almeida ${ }^{1}$, Hermien Tridayanti ${ }^{2}$, Mochammad Arif ${ }^{3}$ \\ victoriakaka25.va@gmail.com¹ ${ }^{1}$ hermien.tridayanti@narotama.ac.id 2, muchamad.arif@narotama.ac.id ${ }^{3}$ \\ Departement of Manajemen, Faculty of Economic and Business, Narotama University Indonesia \\ Jl. Arif Rahman Hakim No.51, Klampis Ngasem, Sukolilo, Surabaya, Jawa Timur 60117 1,2,3
}

\begin{abstract}
Purpose: This study aims to analyze the Effect of Leadership Style and Work Environment on Employee Performance of the Bank Branch Branch (Banco Nacional De Comercio De Timor-Leste) partially and simultaneously.

Design/methodology/approach: This study is quantitative.

Findings: Keywords: Leadership Style, Work Environment, Employee Performance.

Research limitations/implications: 30 employees from all employees in he Bank Branch Branch (Banco Nacional De Comercio De Timor-Leste)

Practical implications: The results of this study indicate that leadership style (X1) does not have a significant effect of 0.224 partially on Employee Performance (Y) and Work Environment (X2) with a significant effect of 0.004 on Employee Performance (Y).

Originality/value:
\end{abstract}

Paper type: This paper can be categorized as case study paper.

Keywords: Leadership Style, Work Environment, Employee Performance.

Received : June $10^{\text {th }} 2019$

Revised : July $17^{\text {th }} 2019$

Published : September $30^{\text {th }} 2019$

\section{INTRODUCTION}

In the world of work today many companies compete to be the best in the business. Then an organization must also have resources that can advance the success of the company in the future. With this phenomenon, the company must have a good work environment because in it there is the leadership that will be the most important factor to be able to work with subordinates so that it can provide its value for the organization and society.

Human resource management is a management activity that includes the utilization, development, assessment, remuneration of humans as members of individual organizations or business enterprises (Sadili, 2006)

A work environment such as space that has not been well organized to be able to build enthusiasm from employees, such as space that does not seem to support the lack of lighting, then all existing problems related to company management will cause organizational performance to decline and the most important is the employee's performance because as a Bank institution in the service sector the priority is satisfaction from customers. Because organizations are government institutions as National Banks must have good performance to be the best. 
The Nacional Bank Comercio of Timor-Leste (BNCTL) is the only bank from the government, so researchers wish to be able to know and analyze leadership style, work environment, and performance.Problems that exist in BNCTL (Bank Nacional de Comercio de Timor-Leste), in the human resources (HR) section are not solid or well-organized, seen from the leadership style possessed by leaders in organizations that do not provide direction for subordinates well.

Leadership. According to (Sunyoto, 2015b), leadership is a process influencing the activities of individuals or groups to achieve goals in certain situations Whereas according to (Sunyoto, 2015b), leadership is every effort of someone who tries to influence the behavior of a person or group, efforts to influence this behavior aim to achieve individual goals, goals of friends, or together with organizational goals may be the same or different.

This behavioral theory focuses on the most important aspects of the leader, but what the leader does depends on the leadership style he applies. There is a basis for a leadership style approach that is believed that effective leaders use a certain style to bring to bear a group or someone to achieve certain goals.

Work Environment. The work environment is a very important part when employees carry out work activities. By observing a good work environment or creating working conditions that can motivate to work, it will influence the enthusiasm of employees in their work (Sunyoto 2015)

Employee Performance Employee Performance is defined by (Dharma, 2009)as a continuous communication process and carried out in partnership between an employee and his immediate supervisor. This process includes activities to build clear expectations and an understanding of the work to be done. This is a system which means having several parts that must all be included if performance management is to provide added value to organizations, managers, and employees.

Performance management aims to establish clear expectations and understanding of:

1. Essential performance functions expected from employees;

2. How great is the employee's contribution to the achievement of organizational goals;

3. What is the concrete meaning of "doing a job better.

4. How employees and supervisors work together to maintain, improve, and develop existing employee performance

5. How will work performance be measured;

6. Recognize various performance barriers and get rid of them.

(Laksmana, Afif, Lapian, Joyce, \& Tumewu, 2015) in their research about The Effect Of Compensation, Leadership, Work Environment, And Training On Employee Performance Of Bank Syariah Mandiri the results of this research indicate that compensation and work environment has a significant positive effect influence on employee performance, while leadership and training have a positive influence but not significant effect on employee performance.

\section{A. CONCEPTUAL FRAMEWORK}

1. The significant influence of leadership and work environment simultaneously on employee performance at Bank BNCTL Branch (National Comersio de Timor Leste Bank).

2. Leadership has a significant effect partially on the performance of employees at Bank BNCTL Branch (National Comersio de Timor Leste Bank).

3. 3. The work environment has a partially significant effect on employee performance at BNCTL Branch (National Comersio de Timor Leste Bank).

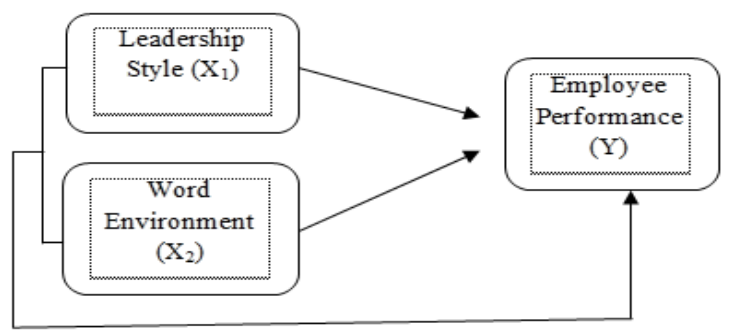

The Effect Of Leadership Style And Work Environment On Employee Performance Of Bnctl Branch Banks (Banco Nacional De Comercio De Timor-Leste)

Victoria Araujo de Almeida ${ }^{1}$, Hermien Tridayanti ${ }^{2}$, Mochammad Arif ${ }^{3}$ 
Figure 1:research concept framework

\section{METHODOLOGY}

This study uses a quantitative approach and this research the population is all employees, namely using the census method at BNCTL Bank, respondents will be taken in this research, 30 employees are in the Branch Bank because the population is relatively small. The types of data used in this research are:

1. Primary Data, are data obtained directly at the research site. This data collection forms by distributing questionnaires.

2. Secondary Data, namely data obtained from the object of research that already exists and is related to this research, which is the organizational structure of the research subject and general description of the organization, discipline or explanation of the position and duties of each.Data analysis techniques used PAWS Statistic (SPSS).

\section{A. RESULTS AND DISCUSSION}

Table 1. Validity and Reliability Test.

\begin{tabular}{|c|c|c|c|c|c|c|}
\hline \multirow[t]{2}{*}{ Variable } & \multirow[t]{2}{*}{ Indicator } & \multirow{2}{*}{$\begin{array}{l}\text { Corrected } \\
\text { Item-Total } \\
\text { Correlation }\end{array}$} & \multirow[t]{2}{*}{$R$ table } & \multirow[t]{2}{*}{ Status } & \multicolumn{2}{|c|}{ Coefficient } \\
\hline & & & & & $\begin{array}{l}\text { Alpha } \\
\text { Cornbach }\end{array}$ & Status \\
\hline \multirow{5}{*}{$\begin{array}{c}\text { Leadershi } \\
\text { p Style } \\
\left(\mathrm{X}_{1}\right)\end{array}$} & $\mathrm{X}_{1.1}$ & .765 & 0,349 & Valid & \multirow{5}{*}{,963 } & \multirow{5}{*}{ Reliabel } \\
\hline & $\mathrm{X}_{1.2}$ & .750 & 0,349 & Valid & & \\
\hline & $\mathrm{X}_{1.3}$ & .754 & 0,349 & Valid & & \\
\hline & $\mathrm{X}_{1.4}$ & .772 & 0,349 & Valid & & \\
\hline & $\mathrm{X}_{1.5}$ & .843 & 0,349 & Valid & & \\
\hline Work & $\mathrm{X}_{2.1}$ & .796 & 0,349 & Valid & \multirow{5}{*}{,963 } & \multirow{5}{*}{ Reliabel } \\
\hline \multirow{4}{*}{$\begin{array}{l}\text { Environm } \\
\text { ent }\left(\mathrm{X}_{2}\right)\end{array}$} & $\mathrm{X}_{2.2}$ & .830 & 0,349 & Valid & & \\
\hline & $\mathrm{X}_{2.3}$ & .909 & 0,349 & Valid & & \\
\hline & $\mathrm{X}_{2.4}$ & .767 & 0,349 & Valid & & \\
\hline & $\mathrm{X}_{2.5}$ & .769 & 0,349 & Valid & & \\
\hline Employee & $\mathrm{Y}_{1.1}$ & .737 & 0,349 & Valid & \multirow{5}{*}{,963 } & \multirow{5}{*}{ Reliabel } \\
\hline Performa & $\mathrm{Y}_{1.2}$ & .679 & 0,349 & Valid & & \\
\hline \multirow[t]{3}{*}{ nce $(Y)$} & $\mathrm{Y}_{1.3}$ & .913 & 0,349 & Valid & & \\
\hline & $\mathrm{Y}_{1.4}$ & .683 & 0,349 & Valid & & \\
\hline & $\mathrm{Y}_{1.5}$ & .858 & 0,349 & Valid & & \\
\hline
\end{tabular}

Source : Processing data by PAWS Stastistic(SPSS 18.0)

From the results in table 1, it can be measured whether or not a result of the questionnaire for all indicators of independent variables and bound shows valid because the value of the total correlation is greater than $r$ table. So it is concluded that all research variables are valid.

And it can be seen that the value of Cronbach's Alpha for all these variables has been reliable or greater than 0.6. From the results that have already been mentioned and can follow the specifications, all research variables are reliable.

Test of Classical Assumptions Normality Test

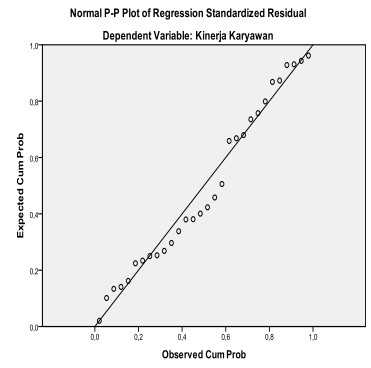


Figure 2. Normality Test Result, Processing data by PAWS Stastistic(SPSS 18.0)

From the results above in figure 2, this graph shows that the points scattered above and below not far from the diagonal line, the results of the test are normally distributed or can meet the assumptions of normality.

\section{Multicollinearity Test}

Tabel 2. Multicollinearity Test

\begin{tabular}{|c|c|c|}
\hline & \multicolumn{2}{|c|}{ Collinearity Statistics } \\
\hline \multirow{4}{*}{$\begin{array}{l}1 \text { (Constant) } \\
\text { Leadership Style } \\
\text { Work Enviroment }\end{array}$} & Tolerance & VIF \\
\hline & & \\
\hline & ,203 & 4,918 \\
\hline & ,203 & 4,918 \\
\hline
\end{tabular}

From the results shown in table 2 above that the test of multicollinearity by looking at the value of VIF from this study is carried by the number 10 or less than 10 , it can be concluded that the multicollinearity test between independent variables is fulfilled or not multicollinearity occurs.

\section{Heteroscedastity Test}

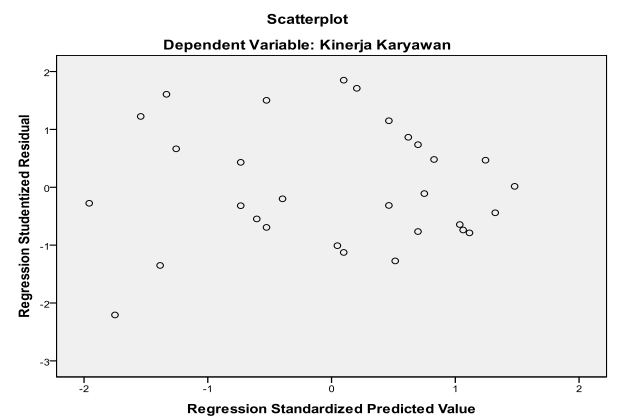

Figure 3. Heteroscedastity Test Result, Processing data by PAWS Stastistic(SPSS 18.0)

From the results above in figure 3, it is known that the distribution of points above and below does not occur as forming patterns (wavy, fused and then narrowing), so the graph above shows that the points spread above and below the number 0 on the axis Y. So it can be concluded that there is no heteroscedasticity.

Analysis of Multiple Linear Regression

Table 3. Analysis of Multiple Linear Regression

\begin{tabular}{|c|c|c|c|c|c|c|}
\hline \multirow[t]{2}{*}{ Model } & & $\begin{array}{l}\text { rdized } \\
\text { ents }\end{array}$ & $\begin{array}{l}\text { Standardiz } \\
\text { ed } \\
\text { Coefficients }\end{array}$ & $\mathbf{t}$ & Sig. & $\begin{array}{l}\text { Collinearity } \\
\text { Statistics }\end{array}$ \\
\hline & B & $\begin{array}{l}\text { Std. } \\
\text { Error }\end{array}$ & Beta & & & $\begin{array}{l}\text { Toler } \\
\text { ance }\end{array}$ \\
\hline
\end{tabular}

The Effect Of Leadership Style And Work Environment On Employee Performance Of Bnctl Branch Banks (Banco Nacional De Comercio De Timor-Leste)

Victoria Araujo de Almeida ${ }^{1}$, Hermien Tridayanti ${ }^{2}$, Mochammad Arif ${ }^{3}$ 


\begin{tabular}{lrrrrrrr}
\hline $\mathbf{1}($ Constant) & 6,052 & 1,413 & & 4,284 &, 000 & & \\
Leadership &, 197 &, 158 &, 252 & 1,244 &, 224 &, 203 & 4,918 \\
$\begin{array}{l}\text { Style } \\
\quad \text { Work }\end{array}$ &, 522 &, 164 &, 647 & 3,192 &, 004 &, 203 & \\
$\quad$ Enviroment & & & & & & &
\end{tabular}

Source : Processing data by PAWS Stastistic(SPSS 18.0)

Multiple linear regression analysis can be formulated as follows:

$$
\mathrm{Y}=6,052+0,197 \mathrm{X} 1+0,522 \mathrm{X} 2+\mathrm{e}
$$

The regression models above have meaning:

1. Constant $(\alpha)=6.052$ shows that the variable Employee Performance (Y) is not influenced by the Leadership variable (X1) and Work Environment (X2), the independent variable $=0$, the value of Employee Performance is 6.052 .

2. Leadership regression coefficient (b1) with a positive value of 0.197 , this shows that if the Leadership variable (X1) is increased, it will increase Employee Performance (Y) by 0.197.

3. 3. Work environment regression coefficient (b2) with a positive value of 0.522 , this shows that if the Work Environment variable (X2) is increased, it will increase Employee Performance (Y) by 0.522.

\section{Coefficient and Determination Analysis}

Table 4. Coefficient and Determination Analysis

\begin{tabular}{|c|c|c|c|c|c|}
\hline \multicolumn{6}{|c|}{ Model Summary ${ }^{b}$} \\
\hline Model & $\mathrm{R}$ & R Square & $\begin{array}{l}\text { Adjusted R } \\
\text { Square }\end{array}$ & $\begin{array}{l}\text { Std. Error of } \\
\text { the Estimate }\end{array}$ & $\begin{array}{l}\text { Durbin- } \\
\text { Watson }\end{array}$ \\
\hline $\begin{array}{ll}0 & 1\end{array}$ &, $880^{\mathrm{a}}$ & ,774 & ,757 & 1,404 & 2,402 \\
\hline
\end{tabular}

The results of the coefficient of determination R2 are used to measure the far ability of the model in explaining non-free variables (Y), namely Employee Performance. Then the results obtained from adjusted $\mathrm{R} 2=0.757$ which means it can be denied from the variables of Leadership (X1) and the work environment that increases discussion in this research.

Partial Hypothesis Testing (t-Test).

Tabel 5. Partial Hypothesis Testing (t-Test)

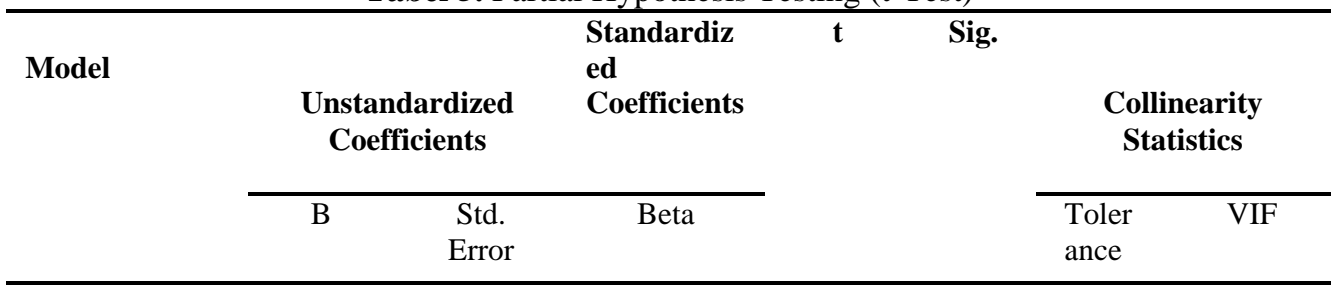




\begin{tabular}{lrrrrrrr}
\hline $\mathbf{1}($ Constant) & 6,052 & 1,413 & & 4,284 &, 000 & & \\
Leadership &, 197 &, 158 &, 252 & 1,244 &, 224 &, 203 & 4,918 \\
$\begin{array}{l}\text { Style } \\
\quad \text { Work }\end{array}$ &, 522 &, 164 &, 647 & 3,192 &, 004 &, 203 & \\
Enviroment & & & & & & &
\end{tabular}

Source : Processing data by PAWS Stastistic(SPSS 18.0)

Based on the results obtained above, $t$ count is 1.244 and t table is 1.703 or with a significance value of $0.224>0.05, \mathrm{H} 0$ is accepted and $\mathrm{H} 1$ is rejected, so that the partial conclusions of the Leadership variable (X1) do not have a significant effect on Employee Performance variables (Y).

Based on the results obtained above, $\mathrm{t}$ count is 3.192 and $\mathrm{t}$ table is 1.703 or with a significance value of 0.04 $<0.05, \mathrm{H} 0$ is rejected and $\mathrm{H} 1$ is accepted, so that the partial conclusions of the Work Environment variable (X2) have a significant effect on the variable Employee Performance (Y). In other words, it can be concluded that the work environment is more guaranteed it will improve the performance of employees.

Simultaneous Hypothesis Testing (F Test)

Table 6. Simultaneous Hypothesis Testing (F Test )

\begin{tabular}{|c|c|c|c|c|c|c|}
\hline \multicolumn{7}{|c|}{ ANOVA $^{\mathrm{b}}$} \\
\hline \multicolumn{2}{|c|}{ Model } & $\begin{array}{l}\text { Sum of } \\
\text { Squares }\end{array}$ & df & Mean Square & $\mathrm{F}$ & Sig. \\
\hline \multirow[t]{3}{*}{1} & Regression & 182,613 & 2 & 91,306 & 46,293 &, $000^{\mathrm{a}}$ \\
\hline & Residual & 53,254 & 27 & 1,972 & & \\
\hline & Total & 235,867 & 29 & & & \\
\hline \multicolumn{7}{|c|}{ a. Predictors: (Constant), Work Enviroment, Leadership Style } \\
\hline \multicolumn{7}{|c|}{ b. Dependent Variable: Employee Performance } \\
\hline
\end{tabular}

Source : Processing data by PAWS Stastistic(SPSS 18.0)

Based on the results above, it can be concluded that Fcount $>\mathrm{F}$ table is 46.293> 3.34, then H0 is rejected at 0.05 significance level, then all independent variables of Leadership (X1) and Work Environment (X2) have a simultaneous effect on dependent variable Employee Performance ( Y). It can be said that the second hypothesis states that Leadership, the Work Environment is jointly towards the Employee Performance of Bank BNCTL branch.

\section{CONCLUSION}

\section{Effect of Leadership on Employee Performance}

The results of the first hypothesis state that Leadership does not have a partial significant effect on Employee Performance. This is in line with research from Danang Afif Laksmana1S.L.H.V. Joyce Lapian2 Ferdinand Tumewu3 (2015) in Bank Syariah Mandiri, the results of her research show that compensation and work environment has a positive effect that has a significant effect on employee performance, while leadership and training have a positive effect but do not significantly influence employee performance.

It can be proven from this study that there is a BNCTL branch bank in the leadership variable of the t-test value which is equal to 1.244 which indicates that the employees in the organization have not been able to carry out their responsibilities properly directed by their superiors. Then Leadership that does not have a significant effect on employee performance is evident in the results of multiple linear regression analysis which concluded that the actual field conditions, namely there are some employees who work do not follow the direction of the leadership, there are also those who do not follow standard procedures from the leadership and company. the employees where they work according to their own volition. 


\section{Effect of Work Environment on Employee Performance}

The results of the second hypothesis state that the Work Environment has a partially significant effect on Employee Performance this is evidenced by the value of the t-test which is equal to 3.192 which indicates that the Work Environment that has been applied by the company can guarantee comfort and calm for employees who work.

So the Work Environment that has a significant effect on employee performance is evident in the results of multiple linear regression analysis which concluded that equal to 0.522, this shows that if the Work Environment variable (X2) is increased, it will improve Employee Performance (Y) of 0.522. This shows that the higher the work environment given by the company, the better the performance of employees.

3. Effect of Leadership and Work Environment on Employee Performance

The results of the third hypothesis state that Leadership and Work Environment have a simultaneous effect on Employee Performance this is evidenced from the value of $\mathrm{f}$ test that is F count> F table which is 46,293> 3.34 then all independent variables of Leadership (X1) and Work Environment (X2) have an effect simultaneously on the dependent variable Employee Performance (Y) is proven to be implicit.

Based on the results of the above research, BNCTL Bank should be able to continue to look back on things that must be improved in leadership so that employees can work in accordance with what is directed by the leadership and maintain a work environment that ensures security so that it can run effectively in order to improve employee performance.

\section{REFERENCES}

Dharma, S. (2009). Manajemen Kinerja. Yogyakarta: Pustaka Pelajar.

Laksmana, Afif, D., Lapian, Joyce, S. L. H. ., \& Tumewu, F. (2015). THE EFFECT OF COMPENSATION, LEADERSHIP, WORK ENVIRONMENT, AND TRAINING ON EMPLOYEE PERFORMANCE OF BANK SYARIAH MANDIRI MANADO. Jurnal Emba, 3(3), 522-532.

Sadili, S. (2006). Manajemen Sumber Daya Manusia. Bandung: Pustaka Setia.

Sunyoto, D. (2015a). Lingkungan Kerja.pdf. Yogyakarta: CAPS (Center of Academic Publishing Service). Sunyoto, D. (2015b). Teori Kepemimpinan (Hersey \& Blanchart, eds.). Yogyakarta: CAPS(Center of Academic Publishing Service). 